\title{
THE FIVE INFORMATION TECHNOLOGY BLIND SPOTS OF ECONOMISTS
}

Eric van Heck evanheck@rsm.nl

Professor at Rotterdam School of Management, Erasmus University, Rotterdam, The Netherlands.

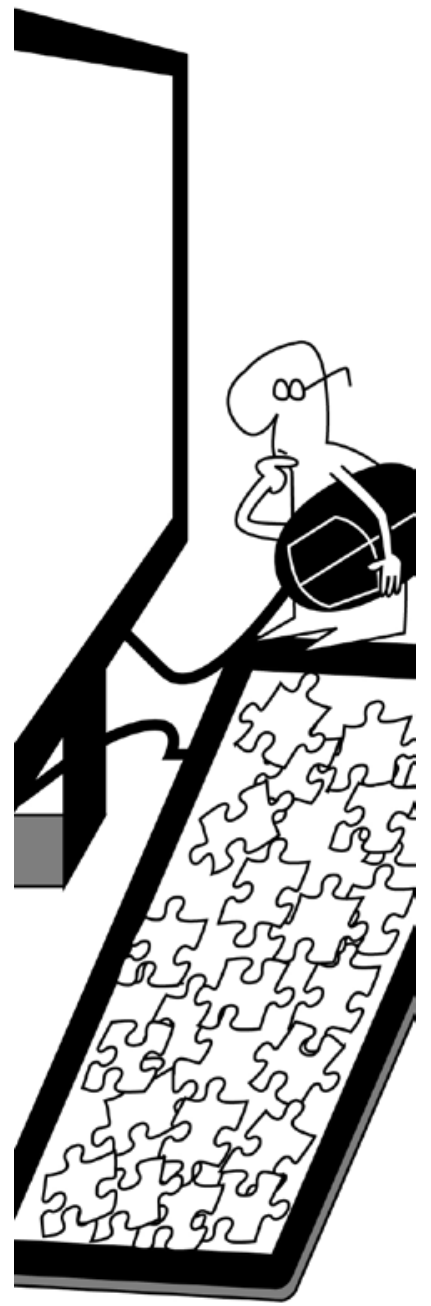

customers to invest even more. The US housing crisis was spreading and became a banking crisis in the US and later in Europe. Most banks survived due to government interventions such as expensive nationalizations of banks. The banking crisis eventually became a sovereign-debt crisis in Europe leading to financial problems for governments in Iceland, Ireland, Portugal, Greece, Italy and Spain. It may also result in breaking up the Euro zone.

An important debate that I would like to discuss here is the role of economists and how they develop economic theory aimed at explaining and predicting the economy, including financial 
booms and busts. As an Information Systems (IS) researcher, my interest is in the role that Information Technology (IT) plays in economic theories. Why did most economists fail to predict the global financial crisis? My answer is simple: most economists have several blind spots with regard to IT. Therefore, they are not fully equipped to analyze and redesign complex financial digitized platforms and products.

Indeed very few economists, both economists working at universities and those working in the financial industry, were able to foresee the weaknesses of the global digitized financial system and identify the consequences and impact of these weaknesses. Examples of some academic economists who did warn about systematic flaws in the financial systems, but not from an IT perspective, were professor Robert Shiller (Yale University) and professor Nouriel Roubini (New York University).

Robert Shiller (together with Karl Case) wrote an article entitled Full House in the Wall Street Journal in August 2006, in which they warned that "there is significant risk of a very bad period, with slow sales, slim commissions, falling prices, rising default and foreclosures, serious trouble in financial markets, and a possible recession sooner than most of us expected." Around that time Nouriel Roubini was interviewed by the Wall Street Journal and declared that: "As the housing sector slumps, the job and income and wage losses in housing will percolate throughout the economy," and "Consumers also face high energy prices, higher interest rates, stagnant wages, negative savings and high debt levels," and "This is the tipping point for the U.S. consumer and the effects will be ugly," and "Expect the great recession of 2007 to be much nastier, deeper and more protracted than the 2001 recession." The article concludes with: "He also sees many of the same warning signs in other economies, including some in Europe." (MARKET WATCH, 2006). So, both professors explained as early as 2006 the development of the US housing bubble and predicted the impact of the housing bubble burst on the rest of the economy. At that time not many people were listening or agreed with their analysis. "While many economists share Roubini's concerns about imbalances in the global economy and in the U.S. housing sector, he stands nearly alone in predicting a recession next year", indicated that same Wall Street journal article of August 23, 2006, and also "FED watcher Tim Duy called Roubini the "the current archetypical Eeyore," responding to a comment Dallas FED President Richard Fisher made last week in referring to economic pessimists as "Eeyores," after Winnie the Pooh's grumpy friend".

Most economists working at universities and in the industry were taken by surprise by the global impact. For example Alan Greenspan, chairman of the FED for almost 19 years, made clear in a US congress hearing in October 2008 that the housing market meltdown had revealed a flaw in a lifetime of economic thinking and left him in a "state of shocked disbelief" (ASSOCIATED PRESS, 2008). Greenspan's "shocking" statement to the US congress can be seen on Youtube, where it is possible to hear from the main financial regulator of the biggest economy in the world that he doesn't "fully understand why and where it happened" (see the US House Oversight Committee questioning Alan Greenspan in October 2008: http://www.youtube.com/ watch?v=txw $4 \mathrm{GvEFGWs).}$

One could argue that economic phenomena are indeed very difficult to analyze and predict due to the fact that one cannot study these phenomena in isolation. There will always be social interaction between the economic phenomena and economists (as active players in the economy). The actions of economists will also have a second-order effect on other stakeholders in the economy. Therefore, it is difficult to theorize about and validate the economic cause-effect relationships. In the so-called beta sciences, such as engineering, chemistry, and biology, it is relatively easier. The object of study is more "under control" and the object is not talking back or taking actions. Bridges, molecules, and plants are not listening to academic research and are not following action.

Another argument is that there is a lack of historical perspective by the economic field and therefore economists need to be humble with regard to the contribution of their academic economic research to society. Nowadays, the economic field in the era of neo-liberalism is dominated by econometrics, and econometric researchers and practitioners are developing very complex models. These models are validated in a very short period of time (from a historical perspective), for example, under real "bull" market (rising) conditions, and not tested under "bear" market 
(declining) conditions. Therefore the generalizability of these complex models is limited but usually quickly applied on a global scale via computerized trading platforms.

Both the social interaction argument and the historical argument hold true. However, I will argue in this "pensata" that there is another and more fundamental argument that plays a role. In my opinion it has to do with the five IT blind spots of economists. Each of these blind spots will be explained and illustrated.

\section{Usage of IT neglected}

The first blind spot is that econometric models usually neglect the role of IT. Here my quip is: "IT is everywhere, except in the models of the economists." This topic has already been debated for many years and is called the "productivity paradox". As pointed out by the Nobel laureate development economist Robert Solow in his article titled "We'd better watch out" published on the New York Times Book Review: "You can see the computer age everywhere but in the productivity statistics". The point economists made was that, although investments in information technology were strong, the impact on output measures, such as higher labor productivity or total factor outputs at the national level, were not seen in the data. Finally, work by Erik Brynjolffson in the 1990s and beyond showed the profound impact of IT on productivity levels. Later work also showed a strong relationship with productivity at the firm level. Erik Brynjolffson and Lorin Hitt, for example, concluded that their results indicate that information systems have made a substantial and statistically significant contribution to firm output.

The financial industry is a heavy user of IT, ranging from quantum trading to exploring new business models with the help of advanced technologies. It is not so much the technology itself (the hardware and software forming digitized trading platforms) but the way the technology is used that will create competitive advantage for firms that are able to use these advanced technologies. The use of IT might improve the efficiency, the effectiveness, or the innovativeness of firms in the financial industry. New financial products, such as credit default swaps, are digitally intensive, both in their design and in their usage. Advanced computerized trading systems are able to trade complex financial products worldwide in nanoseconds. The level of complexity and the level of interconnectedness of the global financial industry due to the usage of IT are profound. According to the Bank for International Settlements (BIS) the global overthe-counter (OTC) derivatives market (forwards and swaps, and options) is 638,928 billion in US dollars (June 2012) (see http://www.bis.org/publ/qtrpdf/r qt1212.htm). On an average trading day, hundreds of thousands of contracts are exchanged between sellers and buyers using advanced information technologies.

More IT savvy firms, in other words firms that use IT as a strategic asset, are able to reap the benefits. They will have the organizational capabilities to design and use digitized platforms and therefore create competitive advantages
(WEILL and ARAL, 2006). The empirical evidence is strong but not much evidence is incorporated in the econometric models.

\section{Flawed measurement of variables in a digitizing world}

Many of the important economic variables are flawed, both in their definition and their measurement as one takes into account the advanced digitization of the economy. Two examples are presented to illustrate this blind spot. The first example deals with inflation. Inflation is a crucial variable for most governments and central banks. Inflation is defined as a rise in the level of prices of goods and services in an economy over a period of time. In most countries inflation is measured in a simple way by buying a certain "basket" of products and services every month and determining the total price level in that month. Usually countries measure a limited set of products and services with a limited frequency (for example, once per month). Recently, Massachusetts Institute of Technology (MIT) announced the Billion Prices project that is constantly measuring prices collected from thousands of online retailers around the world on a daily basis (see http://bpp. mit.edu). The first results show that the real level of inflation is rather different than most economists, politicians, and central bankers anticipated. Outlier is Argentina with a measured average inflation level of $20.1 \%$ over the period 2007 2011, but where the politicians and central bank of Argentina thought it was 8.4\% (CAVALLO, 2012).

The second example relates to the measurement of the Gross Domestic Product (GDP) of a 
country. It refers to the market value of all officially recognized final goods and services produced within a country in a given period. GDP in itself is a strange indicator because it does not matter if it is a good or bad activity. A firm that is polluting the environment is making a great contribution to the GDP, according to the GDP logic (see also BRYSON, 1999). According to MIT researchers Erik Brynjolfsson and Adam Saunders digital products and services are not well accounted for in the GDP, since the information sector is about the same share of GDP it used to be more than 20 years ago, even with the explosive increase of information goods consumption in our lives in the same period. Digital products and services are not very well represented in the GDP data. In short, when one is buying a physical book in a bookshop this transaction will be taken into account in the GDP of the country where the bookshop is situated. However, if a customer orders an electronic book online, for example via Kindle, the e-reader of the online retailer Amazon, the online transaction is not taken into account in the GDP of the country where the electronic book was bought or where the electronic book was used. Therefore, parts of the economy that are heavily digitized, such as electronic books and digital music, and countries that are active in these industries are underrepresented in these GDP measurements.

The ongoing digitalization, consider for example the mobile apps markets, is making the traditional GDP measurement less accurate and not a strong indicator of the final (digital) goods and services produced by a country.
However, GDP is playing a more and more prominent role in the rules for economic and fiscal governance for, for example, the euro-area member states, e.g. the general government deficit must not exceed $3 \%$ of GDP and public debt must not exceed $60 \%$ of GDP (or at least diminish sufficiently towards the $60 \%$ threshold). There is a big need to improve the GDP measurements in a digitized world.

\section{Not much attention to designing complex systems}

In many academic fields "system thinking" is a core activity. Architects are designing complex skyscrapers using tubular systems, e.g. designing a skyscraper to act like a hollow cylinder in order to resist lateral loads (wind, seismic). Biologists are simulating a cell as a system and are looking for enzyme interactions. Chemists use system thinking to understand the complex interactions of atoms. A complex system has interconnected parts that as a whole exhibit one or more properties not obvious from the properties of the individual parts. Complex systems are analyzed and designed by, for example, physicists, biologists, chemists and management scientists. They design complex systems that are robust and flexible. Take for example the work of the physicist Albert-László Barabási on network theory (see for example BARABÁSI, 2010; SONG and others, 2010). In his work he analyzes the structure of so-called scale-free networks that are characteristic for the functioning of systems such as the World Wide Web or the cell as the basic unit of a living organism. Scale-free networks are characterized by few central nodes with many linkages and a powerlaw distribution of the number of links connected to a node. Scalefree networks are usually robust to random failure of nodes, but vulnerable to failure of highly connected nodes. Recent research of the global financial network shows a high connectivity among the different financial institutions and strong interdependency, which makes the network vulnerable to instability (see SCHWEITZER and others, 2009, for a first analysis of the global financial network and its challenges).

Economists are usually not at the forefront in complex systems theory and thus are not very well trained to design and validate complex systems. Systems thinking is considered as too much an "engineer" activity and, given the hierarchy of the paradigms in universities, it is not valued by some academics. However, complex global digitized trading platforms and applications require "soft systems" thinking (CHECKLAND, 1998).

\section{Strict division between macro and micro-economics}

The field of economics is divided between micro-economics and macro-economics. There is not much interaction taking place between those two academic fields. Macro-economists focus on models that analyze and predict the behavior of the economy as a whole. Micro-economists work on the behavior of firms or individuals. However, in practice more macromicro interaction is needed to understand both sides of the same coin. The development and usage of advanced IT, such as social media and visualization technologies, 
will provide the opportunity to link micro behavior of individuals (consumers, employees) to macro policies and vice versa. Google, for example, is doing thousands of experiments, under the guidance of its chief economist Hal Varian, to find out how micro behavior of its clients is related to the design of its applications, such as its key word auction Google Adwords. Experiments deal with varying information strategies that might attract potential consumers to web sites that are ranked higher in Google's key word auctions. The outcome of these experiments provides insights about how the "informedness" of customers might create opportunities both for customers and firms and generate value for the economy as a whole (see LI, 2009). Another example is the aggregation of data with regard to traffic and trade via Google's platform, which will provide information about global trends of products and services and the flow of money that is following the opposite direction of the flow of products and services.

The capabilities to process and analyze big datasets provide academics and practitioners with the possibility of linking microbehavior to macro-outcomes and of creating the knowledge for understanding these complex micro-macro interactions. It is even more complex as suggested by the social scientist Bruno Latour, who is hypothesizing that the micro-macro level is not only a very outdated concept but also incorrect: "the whole is always smaller than its parts". Due to advanced digital technologies and databases Bruno Latour et al. (2012) illustrate that these technologies are able to trace and visualize social phenomena without distinguishing the micro and macro level anymore. Bruno Latour et al. are using the example of exploring the keyword "self-organization" in the Web of Science between 2006 and 2010 using digital visualization technologies. One can explore the network of this keyword that is built using as nodes all keywords, authors, references and addresses of the articles which use the keyword "selforganization". Links between two nodes are created whenever these two entities appear in the same article and weights are attributed to these links depending on the frequency of these co-appearances. Node specialization is performed using a graph layout algorithm for network visualization (LATOUR and others, 2012). Due to these data representation techniques the division between the individual and the whole - in this case the keyword and its network with nodes - becomes obsolete. As Latour et al. discuss: "This is exactly what the striking extension of digital tools is doing to the very notions of 'individual' and 'wholes'. The experience (more and more common nowadays) of navigating on a screen from elements to aggregates may lead researchers to grant less importance to those two provisional end points. Instead of having to choose and thus to jump from individuals to wholes, from micro to macro, you occupy all sorts of other positions, constantly rearranging the way profiles are interconnected and overlapping."

Another example illustrating the role of digital technologies and their impact on micro- and macro-economics is the discussion about the impact of e-money on the different stakeholders in the economy. In their research of M-PESA in Kenya, a short message service (SMS)-based money transfer system that allows individuals to deposit, send, and withdraw funds from a virtual account on their cell phones and that is separate from the banking system, William Jack, Tavneet Suri, and Robert Townsend investigated how existing models of monetary theory can be used to think about the impact of mobile banking on the operations of the financial system and the implications for monetary and regulatory policy decisions that are faced by the central bank. The M-PESA example shows how e-money becomes a part of the economy and how the traditional banking institutions (such as the central bank) are extended with mobile operators (that are handling the e-money accounts). Managing liquidity by the central bank and managing e-liquidity by the mobile operators is just one issue that needs to be carefully analyzed and designed.

These examples show that due to digital technologies the boundaries between microeconomics and macro-economics are blurring and new ways of analyzing, explaining, and predicting economic phenomena are possible.

\section{Decisions by rational man taken for granted}

The dominant paradigm in the field of economics is still the rational model of man. Even though it has been known for a long time that human beings process information differently and also take decisions differently. Outsiders such as the psychologist and sociologist Herbert Simon introduced the concept 
of "bounded rationality" and the psychologist Daniel Kahneman introduced concepts such as "prospect theory" (together with Amos Tversky). Herbert Simon and Daniel Kahneman were awarded the Nobel Prize in Economics in 1978 and 2002 respectively. A central element in the concept of bounded rationality is that the human brain has very limited information processing capabilities. Therefore, human decision makers show "satisficing" behavior, e.g. they are looking for solutions that satisfy the problem at hand. Human decision makers are not looking for optimal solutions given the costs of information processing and the potential future risks at hand.

Humans, as prospect theory explains, are risk-taking to avoid losses and risk-averse for securing gains. A small example will illustrate this. If you ask people to choose between:

A. Getting $\$ 1000$ with certainty;
B. Getting $\$ 2500$ with $50 \%$ chance.

Most pick the first option with the preference for a certain $\$ 1000$, although the second option has a mathematical expectation of $\$ 1250$. The decision indicates risk-averse behavior. If you ask then to choose between:

A. Getting a loss of $\$ 1000$ with certainty;

B. Getting $50 \%$ chance of no loss or a $\$ 2500$ loss.

Most answer the second question with the second option although it is much more risky. This decision indicates risk-seeking behavior. As prospect theory explains: most of us find losses roughly twice as painful as we find gains pleasurable. Prospect theory is a good candidate for explaining trading behavior of humans in financial markets, e.g. to avoid losses, traders will trade more and incur higher losses resulting in trading more, etcetera. In his recent book, Daniel Kahneman provides an excellent overview of the different biases of human decision making.

Both Nobel laureates made clear that full rational decision making is rare and that humans are taking decisions based not only on potential outcomes. Two research directions are seen. The first direction focuses on the behavioral side of decision making and dives into the human brain. Via the use of brain scanning technology (such as functional magnetic resonance imaging (fMRI)) one can detect what part of the brain is used in specific decisions and how decision making in/by the human brain system is done. New fields like neuro-economics, neuro-marketing, and neuroinformation systems are explored. The second direction focuses on the automation of human decision making. Here we enter the world of robotics and intelligent software agents. A recent New York Times article "Skilled Work, Without the Worker" compares the assembly of Apple's iPhones by 1.2 million low-skilled workers in China with the completely robotized factory of Philips in Drachten, the Netherlands. The Philips factory has 128 robotic arms and these are assembling electric shavers. Robots work 365 days a year, 24 hours a day with no coffee breaks. "With these machines, we can make any consumer device in the world," said Binne Visser, an electrical engineer who manages the Philips assembly line in Drachten. Robotics will have some implications for job markets and economies around the world (see also Andrew McAfee's TED Palk at http://www.ted.com/ talks/andrew_mcafee_are_droids_ taking_our_jobs.html).

But not all tasks will be automated immediately. Most human decision making will be supported by intelligent software agents. These agents will have the data processing power and algorithms to support and improve human decision making. These agents are able to learn and can help in complicated supply chain situations both at the tactical and strategic level of decision making (KETTER and others, 2012).

However, most economists, both in academia and in practice, have not been able or have not yet been eager to adopt these concepts in their work. New concepts of human decision making with digital support are needed.

\section{Challenges to overcome these blind spots}

Economists are facing several challenges in transforming the economic field both in the academic and in the business world. The five blind spots that are identified are useful to start designing more IT savvy economic paradigms. Research collaboration between economists and information system researchers is an important step forward. There are several initiatives such as the Economics and Information Systems track at the European and International Conference on Information Systems (ECIS and ICIS) and the Workshop of Information Systems and Economics (WISE) bridging insights from IT and economics 
(more on http://www.wiseconf. org/). But also in economics a new wave of researchers are positioning themselves around initiatives such as the Institute for New Economic Thinking (INET) (more on http://ineteconomics. org/). Also updating the economics curriculum of economics Master and $\mathrm{PhD}$ programs in universities and bringing in elements discussed in the five blind spots will improve the quality of education and provide a new generation of economists. New waves of technologies will continue to evolve and transform the behavior of individuals and societies. The next generation economic models, concepts, and systems will be able to take into account these digital technologies in a robust way. In my opinion developing economic theories is too important to be left only to economists.

\section{NOTE OF APPRECIATION}

I would like to thank Eduardo Diniz (FGV-EAESP) for his excellent comments and suggestions on a previous version of this essay. However, I alone am responsible for all errors.

\section{REFERENCES}

ASSOCIATED PRESS. Greenspan admits 'mistake' that helped crisis. Associated Press, 10.23.2008.

BARABÁSI, A-L. Bursts: the hidden pattern behind everything we do. USA: Dutton Adult, April 2010.

BRYNJOLFSSON, E. The productivity paradox of information technology.
Communications of the ACM, v. 36, n. 12, p. 66-77, 1993.

BRYNJOLFSSON, E; HITT, L. Paradox lost? Firm level evidence on the returns to information systems spending. Management Science, v. 42, n. 4, p. 541-558, 1996.

BRYNJOLFSSON, E; SAUNDERS, A. What the GDP gets wrong (why managers should care). MIT Sloan Management Review, v. 51, n. 1, p. 95-96, 2009.

BRYSON, B. The numbers game. In: Notes from a Big Country, Black Swan, London, p. 65-69, 1999.

CASE. K; SHILLER, R. Full House. The Wall Street Journal, New York, 08.30.2006.

CAVALLO, A. Online and official price indexes: measuring Argentina's inflation, MIT Sloan, Working paper, February, 2012.

CHECKLAND, P. Systems thinking, systems practice. England: John Wiley \& Sons Ltd. 1998.

JACK, W; SURI, T; TOWNSEND, R. Monetary theory and electronic money: reflections on the Kenyan experience. Federal Reserve Bank of Richmond Economic. Quarterly, v. 96, n. 1, p. 83-122, 2010.

KAHNEMAN, D; TVERSKY, A. Prospect theory: an analysis of decision under risk. Econometrica, XLVII, p. 263291, 1979.

KAHNEMAN, D. Thinking, fast and slow, Farrar, Straus and Giroux. New York, 2011.

KETTER, W; COLLINS, J; GINI, M; GUPTA, A; SCHRATER, P. Real-time tactical and strategic sales management for intelligent agents guided by economic regimes. Information Systems Research, v. 23, n. 4, p. 12631283, 2012

LATOUR, B; JENSEN, P; VENTURINI, T; GRAUWIN, S; BOUlliER, D. The whole is always smaller than its parts: a digital test of Gabriel Tarde's monads. The British Journal of Sociology, v. 63, n. 4, p. 590-615, 2012.

LI, T. Informedness and customercentric revenue management, Erasmus Institute of Management, $\mathrm{PhD}$ Series Research in Management, EPS-2009158-LIS, 2009.

MARKET WATCH. Recession will be nasty and deep, economist says. The Wall Street Journal, New York, 08.23.2006.

MARKOFF, J. Skilled work, without the worker. New York Times. 08.18.2012.

NRC HANDELSBLAD. The crisis starts with a meeting of bankers that were stumped. NRC Handelsblad, p. 5, August 9-10, 2012.

SIMON H. Models of bounded rationality. Massachusetts: MIT Press, 1982. 1-2 v; 1997. 3v.

SOLOW, R. We'd better watch out. New York Times Book Review, p. 36, 07.12.1987.

SONG, C; QU, Z; BLUMN, N; BARABÁSI, A-L. Limits of predictability in human mobility. Science, v. $327 \mathrm{n}$. 5968, p. 1018-1021, 2010.

WEILL, P; ARAL, S. Generating premium returns on your IT investments, MIT Sloan Management Review, v. 47, n. 2, p. 38-48, 2006. 